\title{
“Upside Down Decolonization” in Subnational Island Jurisdictions: Questioning the "Post" in Postcolonialism
}

\author{
Godfrey Baldacchino'
}

\begin{abstract}
Most subnational (and mainly island) jurisdictions around the world today are actively conspiring in the dogged pursuit of protracted and extended colonial relationships - what is referred to as "upside down decolonization"-rather than aspiring to full independence.Various metropolitan powers are also discovering that island territories can be excised and rejigged as jurisdictional enclaves, able to perform (and get away with) exceptional functions. These can range from detention centers to low-tax regimes, from military bases to exclusive processing zones. In spite of the lingering rhetoric about the virtues of sovereignty, these "infinite pauses" in decolonization call for a more adequate conceptual assimilation within postcolonial theory.
\end{abstract}

\section{Keywords}

decolonization, enclaves, islands, offshore, sovereignty, subnational jurisdictions, subnationalism, Tokelau, United Nations

\section{Preamble: Tokelau}

The agenda item was nothing short of a face-saving exercise. On June 23, 2009, the United Nations Special Committee on Decolonization once again took up "the question of Tokelau": a non-self-governing island territory in the Pacific, with a total land area of some $12 \mathrm{~km}^{2}$ spread over three scattered atolls, and a resident population of below 1,200 (of which less than 800 were registered voters), administered by New Zealand. The Committee was hard put to reconcile itself to two "independence" referenda in 2006 and 2007, where the adult citizens of Tokelau were asked to choose between their current status quo and a level of self-determination that would preserve New Zealand's support but grant Tokelau formal control over its internal affairs. Both referenda failed to produce the two-thirds majority required to change the territory's non-selfgoverning status ("Tokelau referendum does not produce two-thirds majority," 2006; "Tokelau to remain NZ's last colony," 2007). The Special Committee noted that the Government of New Zealand continued to recognize the right of the territory's people to self-determination but

'University of Prince Edward Island, Charlottetown PE, Canada

Corresponding Author:

Godfrey Baldacchino, University of Prince Edward Island, 550, University Avenue, Charlottetown PE, Charlottetown

CIA 4P3, Canada

Email:gbaldacchino@upei.ca 
acknowledged the decision of the General Fono (the Tokelauan Parliament) that the consideration of any future act of self-determination would be deferred indefinitely. Meanwhile, New Zealand and Tokelau would devote renewed efforts to strengthening essential services and infrastructure, thereby ensuring an enhanced quality of life for the islanders. ${ }^{1}$

That a properly conducted, quasi-independence referendum would fail, twice in a row, may be hard to stomach, especially by a standing UN body mandated expressly to propel the decolonization process to what continues to be seen as an almost natural, logical, and morally appropriate conclusion. Tokelau remains one of 16 non-self-governing territories (of which 14 are islands) on an official UN list that are seen as having yet to graduate to full sovereignty. ${ }^{2}$

But the UN Special Committee may be flogging a dead horse. The majority of Tokelauans want to remain part of New Zealand. In the run-up to the referenda, Tokelauans expressed concerns that New Zealand was seeking to loosen its ties with Tokelau; they sought assurances from the New Zealand Minister of Foreign Affairs that New Zealand would not impose independence on the territory. "Life as a New Zealand colony has brought many benefits to the country. There is no poverty, no unemployment, and full literacy." Some felt that Tokelau lacked the capacity required of a self-governing state. Others simply saw no reason to change: "Only when I'm suffering, then I really want to change. I am not suffering" (quoted in Parker, 2006, p. 75). ${ }^{4}$

\section{A Different Perspective}

One of the overall tenets of postcolonial theory and scholarship has been the need to shift the perspective of how the world is viewed toward that which is held by non-Western people; or, as Robert Young (2003, p. 2) candidly puts it: "turning the world upside down." In attempting to countervail and unhinge the grand historical narratives of the Age of Empire-scripted by the colonizing powers and justifying their heroic, modernizing incursions into the primitive realms of heathens and savages - the voices and histories of the people "on the ground" have been discovered, acknowledged, and celebrated, and various forms of oppression have been exposed. This postcolonial "re-narrativization" displaces a Western "story" of peaceful evolution, selfrighteous supremacy, and capitalist modernity to those anchored in the "imposed violence" of dispersed global peripheries (Hall, 1996, p. 250).

And yet, an uncritical reference to imposed violence may be just as mythical and totalizing as the imperial narrative it has sought to replace. There remains much to be said and understood about smallish remnants of empire where populations (and not just elites) cling stubbornly to nonsovereignty, and where metropolitan-territorial relations may have evolved in fairly sophisticated ways to exploit the opportunities of contemporary rampant globalization. In such places, it has long been evident that colonialism has largely not been "socially or economically problematic" as it had been elsewhere (Connell, 2008, p. 158; also Winchester, 2003). The "passionate yearning for freedom in all dependent peoples"- recognized by the United Nations, in the heyday of decolonization, and implied by Resolution 1514 (XV) of December $1960^{5}$ - is, in most cases, just not there.

To be sure, an anticolonial streak in postcolonialism provides continuity to the ideas and literatures that emerged during the anticolonial struggles across the formerly colonized world (e.g., Young, 2001) - the ethnic cleansing of the indigenous American and Caribbean societies; the evolution and management of the institution of slavery; the migration and consequent diaspora formation of displaced natives (including convicts); the effects of race, culture, class, and gender in postcolonial settings; histories of resistance and struggle against colonial and neocolonial domination; and the complexity of identity formation (e.g., Ashcroft, Griffiths, \& Tiffin, 1995). Although it is probably a necessary antidote to the enduring propaganda of corporate media and the West's effective use of "guns, germs and steel" (Diamond, 1997), this strand of postcolonial 
narrative has met strong criticism: Its suggestion that colonialism, characterized by country-tocountry occupation, is now "post" and therefore "over," is seen as fundamentally flawed and fails to engage with both persisting forms of military subordination as well as other, more subtle, forms of neocolonial supremacy. Moreover, in celebrating subaltern processes, postcolonialism may have merely replaced one set of heroes with another: dramatizing the revolting slave or the leader of the independence struggle, without diagnosing the material context in which these events have taken place and without going on to examine the (possibly corrupt, strangely neocolonial, or just ambiguous) behavior of native leaders, often turned politicians, after their freedom is secured.

There is, meanwhile, another meaning of the "post" in postcolonialism that needs to be acknowledged. This suggests the use of poststructuralist and postmodern forms of sociohistorical analysis. The questioning, and debunking, of the imperial grand narrative persist. Novel forms of intellectual inquiry (such as discourse analysis) are eschewed, and the uncritical adoption of categories such as ethnicity, class, gender, and identity are summarily contested. The perspective is also respectful of multiplicity and plurality while suspicious of how totalizing discourses tend to serve as agents of social control (e.g., Best \& Kellner, 1991). However, as they go about their tasks of deconstruction, these "post" approaches could, given their relativism, playfulness, and undecidability, also disengage with the material (cultural, economic, and political) conditions within which colonial discourses are nested. They have also been rendered in a language of critique inaccessible to all but a few intellectuals who tend to be westernized anyway (e.g., Parry, 2004). So the dominance of Western paradigms of interpretation easily ends up being reinforced, rather than challenged, by the postmodern orientation (no pun intended).

This article proposes a third, different interpretation of "post" in postcolonialism - one driven by the suggestion that the active and dogged pursuit of extended colonial relationships and "upside down decolonization" is yet to be duly accounted for conceptually by postcolonial theory.

\section{Another Way of Turning the World "Upside Down"}

The meaning of "upside down decolonization" in the context of this article is markedly different from what Robert Young intended. The phrase was coined by Dutch scholars in the process of observing the situation in the (formerly) Netherlands Antilles, ${ }^{6}$ whereby it was the metropolis, and not the former colonies, which was pressing the latter for independence (Hoefte \& Oostindie, 1989, 1991). The persisting seven colonial powers - Australia, Denmark, France, the Netherlands, New Zealand, the United Kingdom, and the United States - find themselves in an "enforced colonial condition" while their wards "opt [italics added] for dependency status" (Skinner, 2006, p. 185). This is described rather glibly as "an unusual situation" (Allahar, 2005, p. 132) whereby the mother country seemed willing, even anxious, to free itself from the responsibilities of Empire ${ }^{7}$ but the colonies in question would demur and not let the mother country off the hook (Oostindie \& Klinkers, 2003). Earlier, a similar situation in the neighboring French Département d'Outre Mer of Martinique had been described as a "paradox in paradise" (Miles, 1985).

It would, however, be fairer to state that the above situation is neither unusual nor paradoxical. The politics of "upside down decolonization" are the norm rather than the exception in today's non-independent (and mainly island) territories.

First of all, with some exceptions, sovereignty does not appear to be any longer the obvious trajectory of peoples who see themselves as dispossessed political entities or at the losing end of federalist developments (e.g., Baldacchino \& Milne, 2006; Trompf, 1993). In the contemporary world, there may be solid definitive advantages in not being independent. They may all have their quirks and tendencies-for patronage in particular-yet most of today's populated 
subnational island jurisdictions are functioning democracies and have been so for decades. This suggests that their political economy is working and that the majority of the population must be benefiting sufficiently from current arrangements so as not to opt for radical change. Their territorial elites are generally aware of a few specific but significant economic benefits associated with their jurisdiction's political affiliation. These include the "free riding" afforded to them from the protection of the flag (in areas such as international security, currency, and law and order); the metropolitan oversight that bestows regulatory legitimacy (particularly to offshore finance, which in turn makes their banking and gaming sectors especially attractive to foreign investors and sales corporations); the seamless connectivity with the labor market of a larger, richer country (which allows the metropole's tourists to visit and support the domestic economy while ensuring freedom of movement for the islanders for employment, residence, or education in the metropole, even if as a backup option); and the potential bailout in case of persistent budgetary shortfalls, maladministration, natural disasters, and other (including military) threats.

Second, the case for nonsovereignty may have strong supporters in the metropole, and their arguments represent an ingenious reterritorialization of colonial spaces. A strategic (re)engineering of jurisdiction allows the state to carve out and earmark specific and clearly delineated territory for special, and specialized, services. These include detention camps, quarantine sites, offshore finance centers, low-/no-tax havens, enterprise processing zones, geostrategic military bases, remote weapons testing ranges, toxic waste dump sites, duty-free zones, heritage and conservation parks, spaces without right of abode, and various "mix and match" combinations of the above. In the present imperial moment, we ought to expect more Guantánamo Bays, not fewer (Butler, 2004). The decisions to earmark such spaces in this exceptional manner would not be possible, feasible, or prudent if extended over a state's total territory and population (Reid-Henry, 2007).

And yet, the value-laden discourse of mainstream political science along with the scrutiny of the United Nations Committee on Decolonization belie an enduring obsession with the mantra of sovereignty as an intrinsically laudable, and almost historically unavoidable, evolutionary route. It may be timely to seriously consider a postcolonial theorization that better accommodates such contemporary practices in the spatial transformation of metropolitan-colonial relations, whichpardon the mixed metaphor-take the concept of "upside down" to new heights.

\section{Enduring Colonialism}

The experience of Tokelau is not unique. During the last four decades, referenda in Niue (1974 and 1999), the Cook Islands (1974), Mayotte (1976), the Dutch Antilles (1993 and 1994), Puerto Rico (1967, 1993, and 1998), U.S. Virgin Islands (1993), Bermuda (1995), Dutch Sint Maarten (2000), Bonaire (2004), Saba (2004), Curaçao (2005), and St Eustatius [Statia] (2005) have all rejected independence and typically by huge margins (Bea, 2005; Cohn, 2003; McElroy \& de Albuquerque, 1996). ${ }^{8}$ Aruba cancelled its appointment with independence in 1995, although that had been the key condition for it having been granted status aparte 9 years earlier (Hoefte, 1996). In a 2002 referendum in Gibraltar, albeit without "legal weight," a resounding 98.97\% voted to endorse their current status as a U.K. Overseas Territory (BBC, 2002). In July 1967, in a referendum on Anguilla's secession from the fledgling state of St Kitts-Nevis-Anguilla, 1,813 voted for secession - and thus to revert to the status of a colony of the United Kingdom - and 5 against (Government of Anguilla, 2006). In 2003, voters in both Martinique and Guadeloupe rejected proposals to streamline their administration. Note the choice of words:

The aim of the reform was to eliminate a tier of local government, but many voters appear to have feared it represented a step towards autonomy - in spite of assurances from Paris. (Caribbean Net News, 2003, italics added) 
In most other subnational jurisdictions, there has only been a minimal interest in considering sovereignty; and so, referenda on this matter have not even been proposed. ${ }^{9}$ Indeed, since 1984 , the only small territories to struggle and obtain full independence-in other words, serving as classic examples of decolonization - were the following: (a) East Timor, in May 2002, with its independence referendum in September 1999 endorsed by 78.5\% of voters (e.g., Chomsky, 1999); (b) Montenegro, in June 2006, with an independence referendum narrowly endorsed by $55.4 \%$ of voters (BBC, 2006); and (c) Kosovo, with a unilateral declaration of independence in February 2008 (CNN News, 2008). ${ }^{10}$ Deliberately excluded are the three former members of the Trust Territories of the Pacific: the Federated States of Micronesia, the Marshall Islands, and Palau. Although legally they are sovereign small island states (and members of the United Nations), they are not fully independent (e.g., Jonsson, 1997) but operate within a Compact of Free Association (COFA) with the United States, which accords the political status of free association to these island territories and grants the United States defense rights and obligations, while denying access to these island territories by other third party states (Friberg \& Holen, 2002). Indeed, these three "hybrid jurisdictions" (Levine \& Roberts, 2005) represent attempts at exploiting the advantages of both sovereignty and an autonomy supported by a benign patron state. ${ }^{11}$

How can these manifestations of "upside down decolonization" be explained in a historical context? It appears, in retrospect, that small size and "islandness" may have something to do with this. The four decades of failed independence referenda described above have dealt mainly with small and island jurisdictions. They are the candidates that have remained unaffected by the grand wave of decolonization that has swept the world, creating more than a hundred new sovereign states in its wake. ${ }^{12}$ Indeed, a close look at the sequence of decolonization these past seven decades suggests that territories with larger populations - and their elites-were much more eager to struggle for, and achieve, independence. In fact, there is a clear correlation between population size and year of independence, certainly up to the breakup of the Soviet Union, Yugoslavia, and Czechoslovakia in the early 1990s. The larger the population base of a territory, the earlier has been its achievement of independence (Baldacchino, 2004). The smallest colonies took the longest to achieve independence (if at all), also because their colonial masters had serious doubts to their presumed viability and stability as independent states (Diggines, 1985; Pirotta, Wettenhall, \& Briguglio, 2001; Plischke, 1977). Independence was seen as "an extravagant and improvident recipe for the remaining small territories" (Wainhouse, 1964, p. 133); many of these remaining colonies were deemed "too small by any standards to become independent nations" (Chamberlain, 1985, p. 51). Indeed, the presumed nonviability of small countries was so ingrained that initial attempts at their decolonization were geared toward federative solutions. ${ }^{13}$

And yet, such a historical analysis would be stymied and hopelessly partial if it failed to appreciate an alternative view - that forthcoming "from below" - the policies, strategies, and "agency" of the political and economic elites and non-elites, of small, and in our case, mainly island, jurisdictions. The very smallest colonies have simply refused to toe the independence line. Note this illustrative altercation:

When Suriname was on its way to declare independence in 1975, the Surinamese Premier Henck Arron contacted Juan Evertsz, Premier of the Netherlands Antilles, asking him why the Antilles would not join Suriname and become independent: The reply: "If you will allow yourself to be hanged, it does not mean I will do the same." (quoted in Hoefte \& Oostindie, 1991, p. 75)

Although each case no doubt deserves to be examined on its own merits, there is a pattern in the rationale for refusing independence. Some of the key justifications are pragmatic to the 
extreme: As Sir John Swan, a former Premier of Bermuda (the world's oldest colony?), famously put it in 1982,

With the Americans to feed us and the British to defend us, who needs independence? (quoted in Sanders, 2005).

Most of the current empirical economic literature agrees that subnational dependencies tend to enjoy higher living standards than independent states (Armstrong \& Read, 2000; Betermier, 2004). Using 1998 GNP data for 108 territories (of which 75 are archipelagoes, islands, or on islands), Armstrong and Read (2003) infer the negative impact of sovereignty on per capita income. Using a Pacific data set and ordinary least squares regression, Bertram and Karagedikli (2004) report subnational jurisdictions enjoying per capita incomes 10 times greater than newly independent small states and with no evidence of regional convergence. Bertram (2004, p. 353) also concludes that in the Pacific, "independence did not pay as well as continued political dependence." Similar conclusions are presented from a Pacific and Caribbean data set (McElroy \& Sanborn, 2005).

How is this possible? Poirine (1999) analyzes how metropolitan powers maintain aid flows in exchange for "strategic services," a relationship that is harder to break in nonsovereign territories. Both Connell (1994) and McElroy and Mahoney (2000) explain how political affiliation continues to grant substantial economic advantages to small, nonsovereign, typically island territories. These benefits include the following: free or concessionary trade with, and export preference from, the parent country; social welfare assistance; ready access to external capital through special tax concessions; availability of external labor markets through migration; aid-financed infrastructure and communications; higher quality health and educational systems; natural disaster relief; and provision of costly external defense. Autonomy without sovereignty also does not hinder the development of flourishing tourism economies and may actually facilitate them because of easier terms of access and security. Most of these special conditions have emerged in the context of a history of a relatively benign colonial relationship. Is subnational jurisdictional status one viable, inventive response to this facet of globalization - a part of a jurisdiction's keen instinct for survival (Krasner, 2001)?

\section{Benign Colonial Relations?}

Yet how have these benefits been secured by some territories and not by others? Why have some territories struggled to obtain independence against the desires and plans of their colonial rulers while others have undergone, or experienced, exactly the opposite? ${ }^{14}$ And why has the latter turn of events been most strikingly visible among the world's smallest and enisled jurisdictions?

The answers to these key but difficult questions possibly lie in the manner in which colonial relations were differently introduced, developed, and contested in many small and island locations. First, although small islands have taken the longest to consider independence (Doumenge, 1985), they have also been - with the exception of the Pacific - among the earliest territories to be colonized, so retaining colonial links for longest (Caldwell, Harrison, \& Quiggin, 1980). Feyrer and Sacerdote (2006) go so far as to suggest that the longer an island territory spent as a colony, the higher its present-day living standards and the lower its infant mortality rate: each additional century of European colonization is associated with a $40 \%$ boost in income today and a reduction in infant mortality of 2.6 deaths per 1,000 births. Second, the islands in question may not have had an indigenous population at all —or, if they had one, it had gone extinct - and were thus appropriately "discovered" de novo by Western explorers. ${ }^{15}$ In other cases, the natives - having no hinterland to retreat to (Hintjens, 1991) — were utterly and quickly wiped out following 
contact with the West. This terra nullius scenario conveniently avoided the need to subjugate or somehow come to terms with indigenous populations because they did not (or did no longer) exist. Instead, so many island societies and cultures have thus not been colonized but created ex nihilo by colonial penetration from the outside (Houbert, 1986) - moving effectively from the register of the found to the register of the made (Sloterdijk, 2005). Third, the nature of the colonial impact and experience was, on small islands, not just longer but also more total and intimate: again, the absence of a geographical but also a psychological hinterland meant that an intimate and regular engagement with the colonial presence and its psyche was inevitable for most local island populations. In some cases, it was the only access to formal employment (as in public administration) and formal education. Fourth, many small islands had hardly anything valuable worth exploiting in economic terms: unlike "plantation islands," they were prized, strategic "fortress islands" (Warrington \& Milne, 2007) defending sea routes or sheltered and deep-water harbors. In such a situation, the colonial power just had to ensure the loyalty of the local population: In other words, the sympathy of the locals at large (and not just that of the narrow elite) had to be guaranteed at all costs to maintain the security of the military base. Blatant economic exploitation had thus to be avoided and made way for deliberate strategies of assimilation, through techniques such as opportunities for social advancement through careerist civil service jobs, workfare, and overall benign paternalism.

This interrelated battery of conditions has nurtured colonized nations (and not just the members of their upper classes) with Western tastes, Western ideals, Western languages, and Western religions: "manufactured societies . . creations of empire" (Naipaul, 1972, p. 254). These are clear manifestations of cultural incorporation, even if, at times, fleshed out in non-Western ethnicities (pun intended), even if unrequited by the Colonial motherland. ${ }^{16}$ Even independent island microstates have long been identified as "more Westernized" (Caldwell et al., 1980, p. 960). Microinsular domestic politics have been enthusiastically deployed at forestalling or postponing

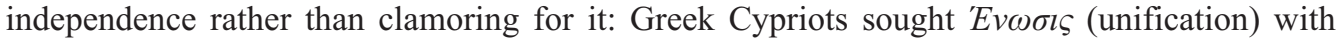
Greece, whereas both Malta and Mauritius went as far as lobbying for integration with Britain, a policy platform that can be described as the very antithesis of decolonization (Baldacchino, 2006; see Note 3). In so many cases, small island dependencies cling proudly and tenaciously to their colonial status (Guillebaud, 1976; Miles, 1985; Winchester, 1985/2003).

And so, "A few colonies did remain, unwilling to let go, or unwilling to stand alone" (Winchester, $1985 / 2003$, p. 339). Couching the situation as an outcome of some form of "unwillingness," however, misses the point: the active pursuit of strategic self-interest by the islanders. It does not acknowledge the very useful "umbilical cord" that connects these island territories with usually benevolent (and at worst indifferent) larger powers and allows the junior partners in the coalition to offload some of their more pressing concerns. In particular, the connection grants asymmetrical citizenship and mobility rights as well as a legitimate claim to state aid and concessionary finance: How else would so many Montserratians have been evacuated to Britain following the mid-1990 eruption of the Soufriere Volcano (e.g., BBC, 2007)? How else would Réunion have financed its new $70-\mathrm{km}$ railway, to be completed by 2014 , operated by a fleet of $100 \mathrm{~km} / \mathrm{h}$ tramtrains (International Railway Journal, 2004)? In contrast, sovereign states in the Pacific — such as the Solomons and Nauru - have risked "state failure" because of acute fiscal and social crises, respectively (Bryant-Tokalau \& Frazer, 2006, passim; Connell, 2006). Sovereign states in the Caribbean complain that those who expound on the benefits of free trade exclude the free shuttling of labor from periphery to core from their equation (e.g., Girvan, 2004). Much of whatever prosperity exists in many remote islands and island territories has come about through overseas aid primarily from the colonial power and through international migration (almost always to the colonial power) and consequent remittances, and this migration was often possible because islanders retained the citizenship of that country (Connell, 2007). 
This is not to dismiss the relevance or significance of local agitation for independence; at some point, even many of these island jurisdictions would have had at least one political party advocating full independence - and that particular party (as in Bermuda, the Faroe Islands, and notably recently in Scotland and French Polynesia) may have also been elected to power and taken over the governance of the jurisdiction by itself or as a member of a ruling coalition.

Nor is this to diminish the lingering interest by the colonial/mainland state in extending its stewardship over island territories. Reasons for this include geostrategic interests, ${ }^{17}$ economic gain, ${ }^{18}$ or the practice of politically correct imperialism: bestowing largesse or rewarding sympathetic governments with investment. ${ }^{19}$ But there is more: the format that such governance over subnational jurisdictions takes on suggests elements of suzerainty, of tributary statehood, of a neotrusteeship, and of a hierarchy of states generally, and all the more so when what is happening on islands is compared with what has been happening in, and to, such mainland flashpoint milieux as Afghanistan, Bosnia, Gaza, Iraq (and Baghdad's Green Zone), Kosovo, Sierra Leone, and Somalia (e.g., Fearon \& Laitin, 2004). In studying export processing zones as responses to the South-East Asian financial crisis of the late 1990s, Ong (2004) identifies a wider resort by governments toward condoning - even creating - a progressively more variegated zonal capitalism or "graduated sovereignty": a "complex and uneven experience of selective boundary crossings, subjectivities and exclusions" (Sidaway, 2007a, p. 352). This device acts to facilitate economic mobility and competitiveness while preserving, or even enhancing, the control of the local state. No contradiction here: it is precisely the "unbundling of territoriality" that enables such an increasingly borderless economy to coexist with a political system based on borders and sovereignty (Hudson, 2000, p. 276; Palan, 1998). The power of states is expressed precisely by a state's ability to craft and condone excised spaces and legal limbos (Agamben, 2005). Such "enclave space" could very well be the new metageography of development (Sidaway, 2007b).

\section{Revisiting Postcolonialism}

Such initiatives are instructive episodes in understanding the epistemologies of contemporary postcolonialism. The impact of the first global financial crisis of the 21 st century has revealed a form of fiscal vulnerability to which Iceland (a sovereign island state) has fallen victim and which has now reopened discussions in that nation about accession to the European Union (e.g., Spiegel On-Line, 2008; BBC, 2009). Autarchy has never been a realistic option for islands, ${ }^{20}$ in spite of a common but fundamentally erroneous opinion that islands are, by geographical disposition, insular, closed, and complete spaces.

If anything, islanders have long been recognized as an internationally mobile citizenry (e.g., Wood, 1967). The ingrained openness of small islands serves to orient their island inhabitants toward the metropole for inspiration, vacation, adventure, shopping, education, and/or employment. Small island literature is dominated by the migration theme (e.g., Brinklow, Ledwell, \& Ledwell, 2000; Markham, 1989). Often, emigration is the only medium that permits a viable "exit" option to the pervasive and stifling totality, monopoly, and intimacy of the local sociocultural environment (Baldacchino, 1997). Islanders from developing nations are known to have a very high propensity to migrate to developed countries (King \& Connell, 1999). The highest proportion of non-OECD graduates living in an OECD country in 2005 were from Guyana, Jamaica, Haiti, Trinidad and Tobago, Fiji, Angola, Cyprus and Mauritius - all but two of which are small island states ("Graduate emigration," 2005). High levels of urbanization at home act to dislodge residents from outlying villages or islands (in the case of archipelagoes) and render them potentially more mobile regionally and internationally (Bertram \& Watters, 1986). For various island households, migration becomes a strategic resource because offspring sent away can be expected to infuse remittances, in cash or in kind, to the home economy, acting as 
a "transnational corporation of kin" (James, 1991; Marcus, 1981). In some instances (e.g., Cape Verde, Philippines, Samoa, and Tonga), these are significant contributions to the home island's gross national income (e.g., Ahlburg \& Brown, 1998). At any point in time, a significant percentage of an island population is likely to be away at its respective metropole(s) (Baldacchino, 1997; Lowenthal, 1987) or even "in transit." There may be no census more difficult to administer than that for a small island population!

Meanwhile, the world is becoming a platform for the scripting of an increasing number of offshore jurisdictional enclaves - a process that could work equally well for larger players who are otherwise unable to execute certain practices on their "home" ground, given their tax codes, gambling regulations, justice system, or regional and international responsibilities. Whether for diverging reasons such as public health, homeland security, or low tax, small islands have been developed - by their erstwhile colonial administrators as much as by their citizens - as niches for differential regulations and "special status." Thus, there seeps in a common, even renewed interest in persisting with colonialism: a strategic permanence. There are more than a $100 \mathrm{such}$ subnational island jurisdictions, some of which are members of federal units but most of which are reengineered ex-/neo-colonial "offshore" spaces, often with the consent and the blessing of the weaker party (Baldacchino, in press). The "rehashing" reflects "mainland-island" relations generally, in that it may be imposed unilaterally from above or nurtured unilaterally from below but is often an outcome of an ongoing process of negotiation and accommodation (Baldacchino \& Milne, 2008).

No doubt, the full consequences of colonialism deserve their voice, and their space, in all their embarrassing detail. Yet postcolonial research (e.g., Le Sueur, 2003) may find it easier to pick on, and grapple with, Algeria rather than Mayotte, India rather than Bermuda, and Indonesia rather than Aruba. The relationship between colonial and postcolonial is not a neatly dialectical one. The postcolonial need not imply the anticolonial, and not even the post colonial (Royle, 2007). ${ }^{21}$ I would quote Edmond and Smith (2003, pp. 5, 6) who affirm that

island stories have tended to slip the net of post-colonial theorizing. . . . Within theories of colonial discourse ... islands are regarded merely as metonyms of imperialism, rather than as specific locations generating their own potentially self-reflective colonial metaphors.

One could draw a similar observation and cautionary note with respect to other fashionable "posts." In presenting themselves as redeeming epistemologies, both poststructuralism and postmodernism can, in practice, act to appropriate and control their subject matter, obviating the relevance and damaging the credibility of alternative explanations (e.g., Tiffin, 1988).

Especially for small islands, there is quite a compelling case to be made today for autonomy without sovereignty. After all,

In an uncertain world, a substantial degree of autonomy, where culture and identity are respected and protected, reasonable access to employment and services exists, and security is guaranteed, has weakened the strength of the claim to independence. (Connell, 2003, p. 141)

\section{Conclusion}

Having "created" offshore, sovereignty and self-determination are themselves constrained and (re-)enabled in turn. (Palan, 1998, p. 625)

Islands have been the sites of some of the most brutal colonial encounters; others have been construed as offloading sites for the metropolitan societies' worst citizens and high-risk patients. 
And yet, pushing any of the current island "colonies" toward independence could be even construed as a "repulsive colonial act" (Hoefte \& Oostindie, 1989, p. 29). Although local politicians may continue to peddle the rhetoric of independence as a long-term goal, progress in that direction appears nevertheless gripped by "an infinite pause" (Connell, 1994, p. 104, 2003) and "sustained autonomy" (Quentin-Baxter, 1994).

In spite of the unambiguous words of former UN Secretary-General, Kofi Annan, colonialism may not be "an anachronism in the 21st century"; it is not necessarily "an unachieved chapter of history." 22 An enduring, even if pragmatic, culture of colonial loyalty plus metropolitan initiatives in political excision, deserve and would benefit from further theorization into postcolonialism. Meanwhile, the lingering colonial administrators may have an exit strategy; it remains important to show that they do so in order to silence the inevitable critics or to appease their own citizenry into what may ultimately prove to be just fictional authority. Yet in all fairness, the metropolitan players may have every intention of permanently thwarting and postponing the implementation of any such departure plan from their subnational units while the locals of these same jurisdictions, appeased by autonomy over policies which matter, may want to make absolutely sure that they do exactly that. Is theirs an enduring, lingering, postmodern neoimperialist alliance? In any case, such unorthodox behavior continues to fly in the face of rationalist theories of international relations (e.g., Amin \& Palan, 2001; Cooley, 2005). It looks like island enclaves, as physicalcum-legal domains, will be with us for some time yet.

\section{Acknowledgments}

My gratitude to Anthony Soares, Stephen A. Royle, and the organizers for inviting me to deliver a keynote address at the Islands and Postcolonialism Conference at Queen's University Belfast, Northern Ireland, in September 2007, for which event the first draft of this article was conceived. Special thanks to Klaus Dodds, Carol Farbotko, Gert Oostindie, Stephen A. Royle, Anthony Soares, Kathleen Stuart, and anonymous reviewers for Space and Culture for comments on earlier drafts. The usual disclaimers apply.

\section{Declaration of Conflicting Interests}

The author declared no conflicts of interest with respect to the authorship and/or publication of this article.

\section{Funding}

The author acknowledges the financial assistance of the Social Sciences and Humanities Research Council of Canada (SSHRC), via a Standard Research Grant 'Offshoring Strategies from/for Subnational Island Jurisdictions’ (SRG Application: 410-2007-0577). The usual disclaimers apply.

\section{Notes}

1. Minutes of the meeting can be found at http://www.un.org/News/Press/docs/2009/gacol3198.doc.htm.

2. For the complete list, visit http://www.un.org/Depts/dpi/decolonization/trust3.htm.

3. Quoted in Sydney Morning Herald, May 31, 2004; Connell (2008, p. 164).

4. For an extended review, see Connell (2008).

5. For the text of the UN Resolution, visit http://www.gibnet.com/texts/un1514.htm.

6. Comprising, until recently, the Caribbean island territories of Bonaire, Curaçao, Sint Maartin, Saba, and St Eustatius (also included Aruba until 1986). The Netherlands Antilles is now being disbanded.

7. This policy stance would also have included returning colonies to appropriate "motherlands"- such as the Falklands to Argentina (Franks, Lord, \& Collaborators, 1983, pp. 5-6, 27) and Hong Kong and Macau to China.

8. Other than the two Tokelau referenda referred to above, the August 1998 vote held in Nevis (Premdas, 2001) was the proverbial exception that justifies the rule: All three were approved by more than $60 \%$ of voters but fell short of a required two-thirds majority for the referenda to succeed. 
9. The key exceptions here would be the following: (a) the Canadian province of Québec, with its 1980 and 1995 referenda - the first securing $40.4 \%$ and the second securing $49.2 \%$ of votes for independence; (b) the deferred independence referendum on Bougainville, an outcome of the 2002 peace accord with Papua New Guinea (Ghai \& Regan, 2006); and (c) the independence referendum expected after 2014 in New Caledonia. Meanwhile, the Scottish National Party-led Government in Scotland is committed to a referendum on Scottish independence.

10. These two cases are actually exceptions that justify the rule because they were both escaping from extensive repression, violence, and insecurity.

11. The Compact of Free Association (COFA) between the United States and the Federated States of Micronesia, and between the United States and the Republic of the Marshall Islands, were signed in 1982, endorsed via referenda in 1983, and ratified in 1986 (COFA, 1985). The COFA with the Federated States of Micronesia was amended in May 2003. The Republic of Palau negotiated a separate Compact with the United States, effective from 1995, after no less than eight referenda.

12. Before World War II, there were 62 independent states; there are 194 at the time of writing (August 2008) and excluding Taiwan.

13. Including the West Indies Federation and Malaya-Singapore, both in the late 1950s to early 1960s.

14. Indeed, in the case of Ireland/Northern Ireland or the Comoros/Mayotte, the contrasting responses to decolonization occurred in the same territory. The same had occurred earlier, but on a much larger scale, in British North America, with Canada emerging as the loyalist option to the rebellious 13 colonies.

15. These "empty islands" included Réunion, Seychelles, Pitcairn, St. Helena, Ascension, Tristan da Cunha, Bermuda, Cayman, and Falklands.

16. Thus, the "right of abode" in the United Kingdom was extended in 2002 to the citizens of all the (mainly non-White) residents of its remaining overseas territories. The 1982 Falklands invasion by Argentina was reportedly "a godsend" because "it acted as a catalyst for renewed British commitment in the South Atlantic" (Dodds, 2002, p. 202). The Chagossians continue to be thwarted of their right of domicile and the Ascension islanders of the right of abode.

17. Consider the military interests of the United States in Diego Garcia, Guam, Marshall Islands, Hawaii, and Okinawa and the former interest of metropolitan France in the South Pacific for nuclear testing purposes.

18. Exclusive Economic Zones can be many times larger than the land area of island territories and often contain large deposits of untapped resources.

19. The International Whaling Commission has become an obvious platform for such benevolence, as has the cold war relating to the securing of diplomatic relations with either the People's Republic of China or Taiwan.

20. The glaring contemporary exception is Cuba, yet this is a situation imposed by the trade embargo of the United States, and it remains in place because the island is relatively large and its equally large population has been necessarily resourceful.

21. Bongie (1998, p. 13) goes further: Inspired by Lyotard, he prefers the variant "post/colonial" because it better describes an "entangled condition" where neither colonialism nor postcolonialism can be defined as clear-cut entities.

22. From his remarks at the opening of the session of the UN Decolonization Committee on February 14, 2004.

\section{References}

Agamben, G. (2005). State of exception (K. Attell, Trans.). Chicago: University of Chicago Press.

Ahlburg, A., \& Brown, R. P. C. (1998). "Migrants" intentions to return home and capital transfers: A study of Tongans and Western Samoans in Australia. Journal of Development Studies, 35, 125-151.

Allahar, A. (2005). Identity and erasure: Finding the elusive Caribbean. Revista Europea de Estudios Latinoamericanos y del Caribe, 79, 125-134. 
Amin, A., \& Palan, R. (2001). Towards a non-rationalist international political economy. Review of International Political Economy, 8, 559-577.

Armstrong, H. W., \& Read, R. (2000). Comparing the economic performance of dependent territories and sovereign micro-states. Economic Development and Cultural Change, 48, 285-306.

Armstrong, H. W., \& Read, R. (2003). The determinants of economic growth in small states. The Round Table: Commonwealth Journal of International Affairs, 92, 99-124.

Ashcroft, A., Griffiths, G., \& Tiffin, H. (Eds.) (1995). The postcolonial studies reader. London: Routledge.

Baldacchino, G. (1997). Global tourism and informal labour relations: The small scale syndrome at work. London: Mansell.

Baldacchino, G. (2004). Autonomous but not sovereign: A review of island sub-nationalism. Canadian Review of Studies in Nationalism, 31, 77-89.

Baldacchino, G. (2006). Managing the hinterland beyond: Two, ideal-type strategies of economic development for small island territories. Asia-Pacific Viewpoint, 47, 45-60.

Baldacchino, G. (in press). Island enclaves: Offshoring strategies, creative governance and sub-national island jurisdictions. Montréal, Canada: McGill Queen's University Press.

Baldacchino, G., \& Milne, D. (2006). Exploring sub-national island jurisdictions. The Round Table: Commonwealth Journal of International Affairs, 95, 487-502.

Baldacchino, G., \& Milne, D. (Eds.). (2008). The case for non-sovereignty: Exploring sub-national island jurisdictions. London: Routledge.

BBC. (2002, November 8). Q\&A: Gibraltar's referendum. BBC News. Retrieved December 29, 2009, from http://news.bbc.co.uk/1/hi/world/europe/2400673.stm

BBC. (2006, May 22). Montenegro chooses independence. BBC News. Retrieved December 29, 2009, from http://news.bbc.co.uk/1/hi/world/europe/5003220.stm

BBC. (2007, July 19). Regions and territories: Montserrat. BBC News. Retrieved December 29, 2009, from http://news.bbc.co.uk/1/hi/world/americas/country_profiles/3666502.stm

BBC. (2009, January 30). Iceland could join EU by 2011. BBC News. Retrieved December 29, 2009, from http://news.bbc.co.uk/2/hi/europe/7860078.stm

Bea, K. (2005). Political status of Puerto Rico: Background, options and issues in the 109th Congress. Retrieved December 29, 2009, from http://www.fas.org/sgp/crs/row/RL32933.pdf.

Bertram, G. (2004). On the convergence of small island economies with their metropolitan patrons. World Development, 32, 343-364.

Bertram, G., \& Karagedikli, O. (2004). Core-periphery linkages and income in small Pacific island economies. In J. Poot (Ed.), On the edge of the global economy (pp. 106-122). Cheltenham, UK: Edward Elgar.

Bertram, G., \& Watters, R. F. (1986). The MIRAB process: Earlier analysis in context. Pacific Viewpoint, 27, 47-59.

Best, S., \& Kellner, D. (1991). Postmodern theory: Critical interrogations. London: Macmillan.

Betermier, S. (2004). Selectivity and the economics of independence for today's overseas territories. Explorations: The UC Davis Undergraduate Research Journal, 7, 63-85.

Bongie, C. (1998). Islands and exiles: The Creole identities of post/colonial literature. Stanford, CA: Stanford University Press.

Brinklow, L., Ledwell, F., \& Ledwell, J. (Eds.). (2000). Message in a bottle: The literature of small islands. Charlottetown, Canada: Institute of Island Studies, University of Prince Edward Island.

Bryant-Tokalau, J., \& Frazer, I. (Eds.). (2006). Redefining the Pacific? Regionalism, past, present and future. London: Ashgate.

Butler, J. 2002. 'Guantanamo Limbo', The Nation, April 1. Retrieved July 4, 2009, from http://www .thenation.com/doc/20020401/butler.

Caldwell, J. C., Harrison, G. E., \& Quiggin, P. (1980). The demography of micro-states. World Development, 8, 953-968. 
Caribbean Net News. (2003, December 9). French Caribbean voters reject change. Retrieved December 29, 2009, from http://www.caribbeannetnews.com/2003/12/09/voters.htm

Chamberlain, M. E. (1985). Decolonization: The fall of the European empires. Oxford, UK: Basil Blackwell. Chomsky, N. (1999, October). East Timor, horror and amnesia. Le Monde Diplomatique. Retrieved December 29, 2009, from http://mondediplo.com/1999/10/02chomsky

CNN News. (2008, February 18). Kosovo celebrates amid Serb protests. Retrieved December 29, 2009, from http://www.cnn.com/2008/WORLD/europe/02/17/kosovo.independence/index.html.

COFA. (1985). Compact of Free Association Act of 1985. Retrieved December 29, 2009, from http://www .fm/jcn/compact/actindex.html.

Cohn, P. (2003). Economic independence through expansion of private sector enterprise: The "prescriptive unreality" of Niue's development planning (Working Paper No. 11). Melbourne, Australia: Melbourne University, School of Development Studies. Retrieved December 29, 2009, from http://www.sages .unimelb.edu.au/research/workingpapers/pdf/wp11.pdf

Connell, J. (1994). Britain's Caribbean colonies: The end of the era of decolonization. The Journal of Commonwealth and Comparative Politics, 32, 87-106.

Connell, J. (2003). New Caledonia: An infinite pause in decolonization? The Round Table: Commonwealth Journal of International Affairs, 92, 125-143.

Cooley, A. (2005). Logics of hierarchy: The organization of empires, states and military occupations. Ithaca, NY: Cornell University Press.

Connell, J. (2006). Nauru: The first failed Pacific state? The Round Table: Commonwealth Journal of International Affairs, 95, 47-63.

Connell, J. (2007). Island migration. In G. Baldacchino (Ed.), A world of islands (pp. 455-482). Canada and Malta: Institute of Island Studies and Agenda Publishers.

Connell, J. (2008). "We are not ready": Colonialism or autonomy in Tokelau. In G. Baldacchino \& D. Milne (Eds.), The case for non-sovereignty: Lessons from sub-national island jurisdictions (pp. 157-169). London: Routledge.

Diamond, J. (1997). Guns, germs and steel: The fates of human societies. New York: W. W. Norton.

Diggines, C. (1985). The problems of small states. The Round Table: Commonwealth Journal of International Affairs, 74, 191-205.

Dodds, K. (2002). Pink ice: Britain and the South Atlantic empire. London: I. B. Tauris.

Doumenge, F. (1985). The viability of small inter-tropical islands. In E. C. Dommen \& P. L. Hein (Eds.), States, microstates and islands (pp. 70-118). London: Croom Helm.

Edmond, R., \& Smith, V. (Eds.) (2003). Islands in history and representation. London: Routledge.

Fearon, J. D., \& Laitin, D. D. (2004). Neotrusteeship and the problem of weak states. International Security, 28, 5-43.

Feyrer, J., \& Sacerdote, B. (2006). Colonialism and modern income: Islands as natural experiments (NBER Working Paper No. 12546). Cambridge, MA: National Bureau for Economic Research.

Franks, Lord, \& Collaborators. (1983). The Franks Report: Falkland Islands Review. London: Her Britannic Majesty's Stationery Office.

Friberg, E., \& Holen, L. (2002, June). The Compact of Free Association: The U.S. experience in Micronesia. Paper presented at the Islands of the World VII conference, University of Prince Edward Island, Canada.

Ghai, Y. P., \& Regan, A. J. (2006). Unitary state, devolution, autonomy, secession: State building and nation building in Bougainville, Papua New Guinea. The Round Table: Commonwealth Journal of International Affairs, 95, 589-608.

Girvan, N. (2004, November). Do small islands have a future in a globalized world? Paper presented at the Islands of the World VIII conference, Kinmen Island, Taiwan.

Government of Anguilla. (2006). Introduction to constitutional reform. Retrieved December 29, 2009, from http://gov.ai/images/constitutional\%20reform/4.\%20Introduction\%20final.pdf 
Graduate emigration. (2005, March 31). The Economist. Retrieved December 29, 2009, from www .economist.com/markets/indicators/displaystory.cfm?story_id=E1_PRTSDGR

Guillebaud, J. C. (1976). Les Confettis de l'Empire. Paris, France: Seuil.

Hall, S. (1996). When was the postcolonial? Thinking at the limit. In I. Chamber \& L. Curtis (Eds.), The post-colonial question: Common skies, divided horizons (pp. 242-260). London: Routledge.

Hintjens, H. M. (1991). France in the Caribbean. In P. K. Sutton (Ed.), Europe and the Caribbean (pp. 37-70.). London: Macmillan.

Hoefte, R. (1996). Thrust together: The Netherlands Relationship with its Caribbean partners. Journal of Interamerican Studies and World Affairs, 38(4), 35-54.

Hoefte, R., \& Oostindie, G. (1989). Upside-down decolonization. Hemisphere, 1(2), $28-31$.

Hoefte, R., \& Oostindie, G. (1991). The Netherlands and the Dutch Caribbean: Dilemmas of decolonization. In P. K. Sutton (Ed.), Europe and the Caribbean (pp. 71-98). London: Macmillan.

Houbert, J. (1986). Reunion-I: Decolonization in the Mascareignes. Journal of Commonwealth and Comparative Politics, 18, 145-171.

Hudson, A. C. (2000). Offshoreness, globalization and sovereignty: A post-modern geo-political economy? Transactions of the Institute of British Geographers, 25, 269-283.

James, K. E. (1991). Migration and remittances: A Tongan village perspective. Pacific Viewpoint, 32, 1-23.

Jonsson, I. (1997, March). From home rule to independence? New opportunities for a new generation in Greenland. Paper presented at symposium on Dependency, Autonomy and Conditions for Sustainability in the Arctic Nuuk. Retrieved December 29, 2009, from http://www.bifrost.is/Files/Skra_0008050.pdf

King, R., \& Connell, J. (1999). Small worlds, global lives: Small islands and migration. London: Pinter.

Krasner, S. D. (2001, February). Think again: Sovereignty. Foreign Policy. Retrieved December 29, 2009 , from http://www.globalpolicy.org/nations/realism.htm

Le Sueur, J. (Ed.). (2003). The decolonization reader. London: Routledge.

Levine, S., \& Roberts, N. S. (2005). The constitutional structures and electoral systems of Pacific island states. Commonwealth and Comparative Politics, 43, 276-295.

Lowenthal, D. (1987). Social issues. In C. G. Clarke \& T. Payne (Eds.), Politics, security and development in small states (pp. 26-49). London: Allen and Unwin.

Marcus, G. E. (1981). Power on the extreme periphery: The perspective of Tongan elites in the modern world system. Pacific Viewpoint, 22, 48-64.

Markham, E. A. (Ed.). (1989). Hinterland: Caribbean poetry from the West Indies and Britain. Newcastle upon Tyne, UK: Bloodaxe Books.

McElroy, J. L., \& de Albuquerque, K. (1996). The social and economic propensity for political dependence in the insular Caribbean. Social and Economic Studies, 44, 167-193.

McElroy, J. L., \& Mahoney, M. (2000). The propensity for political dependence in island microstates. Insula: International Journal of Island Affairs, 9, 32-35.

McElroy, J. L., \& Sanborn, K. (2005). The propensity for dependence in small Caribbean and Pacific islands. Bank of Valletta Review (Malta), 31, 1-16.

Miles, W. F. S. (1985). Elections and ethnicity in French Martinique: A paradox in paradise. New York: Praeger.

Naipaul, V. S. (1972). The overcrowded barracoon and other articles. London: André Deutsch.

Ong, A. (2004). The Chinese axis: Zoning technologies and variegated sovereignty. Journal of East Asia Studies, 4, 69-96.

Oostindie, G., \& Klinkers, I. (2003). Decolonizing the Caribbean: Dutch policies in a comparative perspective. Amsterdam: Amsterdam University Press.

Palan, R. (1998). Trying to have your cake and eating it: How and why the state system has created offshore. International Studies Quarterly, 42, 625-643.

Parker, I. (2006, May 1). Birth of a nation? The New Yorker, pp. 66-75. Retrieved December 29, 2009, from http://www.newyorker.com/archive/2006/05/01/060501fa_fact_parker

Parry, B. (2004). Postcolonial studies: A materialist critique. London: Routledge. 
Pirotta, G. A., Wettenhall, R., \& Briguglio, L. (2001). Governance of small jurisdictions: Guest editors' introduction. Public Organization Review, 1, 149-165.

Plischke, E. (1977). Microstates in world affairs. Washington, DC: American Enterprise Institute for Public Policy Research.

Poirine, B. (1999). A theory of aid as trade with special reference to small islands. Economic Development and Cultural Change, 47, 831-852.

Premdas, R. R. (2001). Identity and secession in a small island state: Nevis. Canadian Review of Studies in Nationalism, 28(1-2), 27-44.

Quentin-Baxter, A. (1994). Sustained autonomy: An alternative political status for small islands? Victoria University of Wellington Law Review, 24, 1-18.

Reid-Henry, S. (2007). Exceptional sovereignty? Guantánamo Bay and the re-colonial present. Antipode, $39,627-648$.

Royle, S. A. (2007, September). Postcolonial but not Post-colonial: The UK's overseas territories. Paper presented at Islands and Postcolonialism Conference, Belfast, UK.

Sanders, R. (2005, March 8). Bermuda: Independence or not? Caribbean Net News. Retrieved December 29, 2009, from http://www.caribbeannetnews.com/2005/03/08/sanders.shtml

Sidaway, J. D. (2007a). Spaces of postdevelopment. Progress in Human Geography, 31, 345-361.

Sidaway, J. D. (2007b). Enclave space: A new metageography of development? Area, 39, 331-339.

Skinner, J. (2006). Formal and informal relations on colonial Montserrat and Gibraltar. In J. Skinner \& M. Hills (Eds.), Managing island life: Social, economic and political dimensions of formality and informality in island communities (pp. 181-205). Dundee, Scotland, UK: University of Abertay Press.

Sloterdijk, P. (2005). Écumes: Sphérologie Plurielle. Paris, France: Maren Sell Éditeurs.

Spiegel On-Line. (2008, June 10). Credit crisis woes: Iceland's financial woes could push it closer to EU. Retrieved December 29, 2009, from http://www.spiegel.de/international/business/0,1518,582487,00.html

Tiffin, H. (1988). Post-colonialism, post-modernism and the rehabilitation of post-colonial history. Journal of Commonwealth Literature, 23, 169-181.

Tokelau referendum does not produce two-thirds majority. (2006, February 16). Scoop News. Retrieved December 29, 2009, from http://www.scoop.co.nz/stories/PA0602/S00232.htm

Tokelau to remain NZ's last colony. (2007, October 25). Sydney Morning Herald. Retrieved December 29, 2009, from http://www.smh.com.au/news/WORLD/Tokelau-to-remain-NZs-lastcolony/2007/10/25/1192941226714.html

Tram-Train (2009) Le debut d'une histoire. Retrieved, January 6 2010, from http://www.tramtrain.fr/. On page 7, 9th line from bottom, REPLACE International Railway Journal, 2004 WITH Tram-Train, 2009.

Trompf, G. (Ed.). (1993). Islands and enclaves: Nationalisms and separatist pressures in island and littoral contexts. New Delhi, India: Sterling.

Wainhouse, D. (1964). Remnants of empire. New York: Harper and Row for the Council on Foreign Relations.

Warrington, E., \& Milne, D. (2007). Island governance. In G. Baldacchino (Ed.), A world of islands (pp. 379-428). Canada and Malta: Institute of Island Studies and Agenda Publishers.

Winchester, S. (2003). Outposts: Journeys to the surviving relics of the British empire. Sevenoaks, UK: Sceptre Books.

Wood, D. P. J. (1967). The smaller territories: Some political considerations. In B. Benedict (Ed.), Problems of smaller territories (pp. 23-34). London: Athlone Press for the Institute of Commonwealth Studies.

Young, R. (2001). Postcolonialism: An historical introduction. Oxford, UK: Blackwell.

Young, R. (2003). Postcolonialism: A very short introduction. Oxford, UK: Oxford University Press.

\section{Bio}

Godfrey Baldacchino is Canada Research Chair (Island Studies), University of Prince Edward Island, Canada; visiting professor of sociology, University of Malta, Malta; executive editor, Island Studies Journal; and moderator, www.islandstudies.ca. 